\title{
Scientific Literacy as Foundation in Character Building for Early Childhood and Elementary Grade School
}

\author{
Yanti Fitria \\ Universitas Negeri Padang \\ yanti_fitria@fip.unp.ac.id
}

\begin{abstract}
Children at an early age (early childhood) including the grades of elementary school is a human figure that has a lot of uniqueness and rich imagination. Therefore, they must be facilitated in order to develop their potential through by providing many experiences of interacting with the natural surroundings and the natural environment of social life. One way that can be done is through the development of science learning. Development of science learning in early childhood including other development has a very important role in building the foundation or foundation of the ability and the establishment of a strong character for quality human resources. Awareness of the importance of science in children will be higher if we realize that we live in a dynamic and changing world continuously, the more complex the scope, and of course will increasingly require science. So future predictions of life's challenges make science's binding for children absolute and science embedded within them as a way of seeking truth in future lives. They must be equipped with strong literacy skills in accordance with early childhood development until the grade elementary school, especially aspects of language development including reading, speaking and writing skills.
\end{abstract}

Keywords-character education; early childhood; elementary grade school; scientific literacy

\section{INTRODUCTION}

One of the important skills to increase knowledge and problem-solving abilities is science literacy [18]. Literacy Science is also one of the sphere of study Programmed for International Student Assessment [15]. In the context of PISA, scientific literacy is defined as the ability to engage with science-related issues, and with the ideas of science, as a reflective citizen. PISA explained that science literacy is the ability to engage with science-related issues, and with the notion of science, as a reflective citizen. Yore suggests that in order for this literacy to be well embedded from the start of school it is important to develop the child's oral language skills well as a basis for the development of science literacy [1
]. Literacy of science is considered very important because it is a basic competence for learners in understanding various aspects of life. Scientific attitude is one of the most important results of this science literacy learning. Some argue that a scientific attitude is as important as knowledge. To develop a scientific attitude, teachers should always pay attention to the questions and the spirit of the inquiry so that science is not just the acceptance of dogma [18]. Forward four basic attitudes that must be developed in Science that is (a) curiosity, (b) inventiveness, (c) critical thinking, and (d) persistence [2]. These four attitudes cannot be separated from one another because of complementarity. Curiosity encourages the discovery of something new (inventiveness) that with critical thinking will affirm persistence and dare to differ. American Association for Advancement of Science [3]; [4] emphasizes the four attitudes that are necessary for the primary school level ie honesty, curiosity, open minded, and skepticism. At this time science literacy in Indonesia tends to be teacher centered, where teachers teach science only as a product. Learners only memorize concepts, theories, and laws. In addition, science literacy learning is only oriented to the exam / test. As a result, learners only study science on low cognitive domains only [5]. In fact, the cognitive development of learners based on the movement, deeds and characters [6]. Teachers as educators should play a role preparing learning activities that can encourage learners to ask, observe, experiment, and find facts and concepts themselves.

\section{LITERATURE REVIEW}

\section{A. Meaning of Science Literacy}

PISA defines science literacy as the ability to use science knowledge, identify questions, and draw conclusions based on evidence in order to understand and make decisions regarding nature and its changes due to human activities [13]. Deboer state that Scientific literacy was to provide a broad understanding of science and of the rapid developing scientific enterprise whether one was to become a scientist or not [7]. That is, science literacy is for all students, regardless of whether the student will become a scientist or not. While 
National Science Education Standards [8] state that Scientific literacy is knowledge and understanding of scientific concepts and processes required for personal decision making, participation in civic and cultural affairs, and economic productivity. Students with less developed literacy skills are able to resolve problems in simple and familiar situations, while students with more developed literacy skills are able to resolve problems in complex and less familiar situations. In contrast to PISA, National Science Education Standards (NSES) in National Research Council using term scientifically literate and scientifically illiterate [9]. An image of someone who scientifically literate or people who have deep science literacy.

Norris dan Philips in Holbrook \& Rabbikmae adding an attitude component in science literacy, namely: independence in learning science, the ability to think scientific, curiosity, and the ability to think critically. Even farther, Graber in Holrook \& Rannikmae describes competence-based science literacy model is the result of intersection between what do people know (consists of the competence of science and epistemological competence), what do people value (consists of ethical/moral competence), and what can people do (consisting of learning competencies, social competence, procedural competency, and communication competence)[10] [10]; [11].

\section{B. Explanation of Dimensions in Literacy of Science}

Scientific literacy is defined as the ability to use science knowledge, identify questions and draw conclusions based on evidence, in order to understand and make decisions regarding nature and changes made to nature through human activities [12]. This definition of science literacy considers science literacy to be multidimensional, not just an understanding of scientific knowledge, but broader than that. In PISA 2006 the science literacy dimension was developed into four dimensions, the addition of the students' attitudes toward science [13]. Aspects of context; The points of the PISA assessment focus on situations that relate to individual, family and individual (personal), community-related, and related to life across countries (global). Aspects of content; Refers to the key concepts of science required to understand natural phenomena and the changes made to nature through human activity. Aspects of competency (process); To build students' scientific inquiry skills based on logic, reasoning and critical analysis, and divided into the following three aspects: (a) Identify scientific questions, (b) Explain the phenomenon scientifically, (c) Using scientific evidence. Aspects of attitude (character); he ultimate goal of science education is to help students develop students' interest in science and support scientific inquiry. Attitudes to science play an important role in student decisions to develop further science knowledge, pursue careers in science, and use scientific concepts and methods in their lives. That way, PISA's view of science's ability is not only skill in science, but also their nature of science. The ability of a person's science contains certain attitudes, such as trust, motivation, self-understanding, and values.

\section{ChaRACTER BUILDING}

There are three different words about the meaning of the word character, namely ethics, morals, and characters that each have a slightly different meaning. The word moral has the same meaning as ethics, although the origin of the word is different. Ethics comes from words ethos (Egypt) meaning custom, custom, morals, character, while the moral comes from the word mos (Latin) meaning custom, custom. Moral will determine one's personal character.

Berkowitz said that character is an individual's set of psychological character-istics that affect that person's ability and inclination to function morally. This explains that the character is a set of psychological characteristics of a person that affects the ability and inclination of the person to function morally [14]. Adisusilo states that character is something that qualifies a person, character becomes identity, becomes characteristic, becomes a fixed trait, which transcends the ever-changing contingent experience [1][15].

While Naim suggests that the character is a series Attitude, behaviors, motivations, and skills [16]. Characters include attitudes such as the desire to do the best, intellectual capacity, such as critical attitudes and moral reasons, behaviors such as honest and responsible, defending moral principles in situations of injustice, interpersonal and emotional skills that enable one to interact effectively in various circumstances, and commitment to contribute to the community and society. Kemendiknas suggests that character is the character, character, morality, or personality formed by the internalization of virtues that are believed and used as the basis for the worldview, thinking, attitude and action [17].

\section{SCIENCE LITERACY AS A FORUM FOR STRENGTHENING STUDENT CHARACTER}

One aspect of the scientific literacy dimension in PISA is the strengthening of characters. According to Piaget's theory cited by Aiken, a child becomes aware of and understands science through interaction and adapting to the environment [2]. It requires characters that strengthen the character of the teacher and the curriculum. Learning science that uses factual approach primarily aims to introduce students to various facts in science. Table 1 below presents the types of characters that can be developed through the learning process of science literacy.

Table 1. Types of Character Can Be Developed Through Skill ActivityLearning Process of Science Literacy For Early Childhood and Grade Elementary School 


\begin{tabular}{|l|l|}
\hline $\begin{array}{l}\text { Activity Process } \\
\text { Skills }\end{array}$ & Characters that Can Be Developed \\
\hline Observing & $\begin{array}{l}\text { honest, disciplined, hard work, creative, } \\
\text { independent, cooperation, curiosity, } \\
\text { responsibility }\end{array}$ \\
\hline Classifying & $\begin{array}{l}\text { honest, disciplined, hard work, creative, } \\
\text { independent, cooperation, curiosity, } \\
\text { responsibility }\end{array}$ \\
\hline communicating & $\begin{array}{l}\text { friendly, democratic, tolerant, religious, } \\
\text { peace-loving, cooperative, caring } \\
\text { social, caring environment }\end{array}$ \\
\hline Measurement & $\begin{array}{l}\text { honest, disciplined, hard work, creative, } \\
\text { independent, cooperation, curiosity, } \\
\text { responsibility }\end{array}$ \\
\hline Making prediction & creative, curiosity, happy to read \\
\hline Making inference & creative, curiosity, happy to read \\
\hline
\end{tabular}

Activities the children are invited to concrete objects to be able to do it by playing and observing facts or reading the source of learning science. An important ability in early childhood or early school development is language skills such as literacy. Low reading ability is associated with low school performance, low literacy skills, implications for increased behavioral problems and dropout rates. The belief in the partial holistic literacy of parents, family routines, and the use of multimedia technology is not a determinant of a child's initial literacy abilities. Literacy activities at home also have not functioned optimally to develop the initial literacy of children. The family literacy has not developed yet the paradigm of the family as an asset or capital for the development of the initial literacy potential of the child has not been created. Contextual early literacy activities can be done by playing and reading books compared to direct teaching.

\section{Conclusions}

Every citizen has the level of science literacy in order to survive in nature and in his place of work armed with knowledge, understanding, skills and values contained therein. Literacy is defined as the capacity of students to apply knowledge and skills and to analyze, reason and communicate effectively when they are faced with problems, must resolve and interpret problems in various situations. PISA study covers the scope of science literacy aspects of content dimension, process, and attitude/ character. Material or science content is not directly related to the curriculum in any country. The science process in PISA covers the use of science knowledge in solving everyday problems and making decisions. Context dimensions include context-specific issues that are important in life in general as well as the strengthening of the learner's character. In realizing one context of science literacy in learning that attitudes and characters inculcated through science activities directly in learning is not just focus on cognitive knowledge alone or transfer of knowledge of teachers to the child's brain. But more than that learning science literacy is expected to be a container of strengthening the character for learners which is needed in the face of the development of advanced science and help learners in solving real-life problems.

\section{Acknowledgment}

The authors would like to thank Dean of Faculty of Education, Universitas Negeri Padang for support of this study.

\section{References}

L. Yore, et al., "Examining the literacy component of science literacy: 25 years of language arts and science research," International journal of science education, vol. 25, pp. 689-725, 2003.

[2] I. W. Suastra, "Pembelajaran sains terkini," Singaraja: Undiksha, 2009.

[3] B. Latour, "From the world of science to the world of research?," Science, vol. 280, pp. 208-209, 1998.

[4] F. W. Horton, "Understanding information literacy: A primer," ed: Unesco Paris, 2008.

[5] M. P. Trianto, "Mengembangkan Model Pembelajaran Tematik," Penerbit: PT. Prestasi Pustakaraya-Jakarta. Hal, vol. 74, 2010.

[6] C. Semiawan, et al., Pendekatan Ketrampilan Proses: Bagaimana Mengaktifkan Siswa dalam Belajar?, 1989.

[7] G. E. DeBoer, A History of Ideas in Science Education: Implications for Practice: ERIC, 1991.

[8] B. Welch, Physiological Effects of Noise: Based upon papers presented at an international symposium on the Extra-Auditory Physiological Effects of Audible Sound, held in Boston, Massachusetts, December 28-30, 1969, in conjunction with the annual meeting of the American Association for the Advancement of Science: Springer Science \& Business Media, 2012.

[9] P. E. Barton, "National Education Standards: Getting beneath the Surface. Policy Information Perspective," Educational Testing Service, 2009.

[10] J. Holbrook and M. Rannikmae, "The meaning of scientific literacy," International Journal of Environmental and Science Education, vol. 4, pp. 275-288, 2009.

[11] S. P. Norris and L. M. Phillips, "How literacy in its fundamental sense is central to scientific literacy," Science education, vol. 87, pp. 224-240, 2003.

[12] H. Firman, "Laporan Analisis Literasi Sains Berdasarkan Hasil PISA Nasional Tahun 2006," Jakarta: Pusat Penilaian Pendidikan Balitbang Depdiknas, 2007.

[13] R. Woodward, The organisation for economic Co-operation and development (OECD): Routledge, 2009.

[14] M. W. Berkowitz, et al., "What works in character education: What is known and what needs to be known," Handbook of moral and character education, pp. 414-431, 2008.

[15] S. Adisusilo, "Pembelajaran Nilai-Karakter: Konstruktivisme dan VCT sebagai Inovasi Pendekatan Pembelajaran Afektif," Jakarta: Rajawali Pers, 2012.

[16] N. Naim, "Character Building," Jogjakarta: Ar-Ruzz Media, 2012.

[17] T. Penyusun, "Panduan Integrasi Pendidikan Karakter dalam Pembelajaran IPA di Sekolah Dasar," Jakarta: Kemendikbud, 2012. 